\title{
Comparative Analysis of Thermodynamic Efficiency of Cycles for Various Flowcharts of Refrigerating Unit
}

\author{
Larisa Vladimirovna Sumzina, Aleksandr Vasilievich Maksimov, Yuriy Vladimirovich Kudrov \\ Russian State University of Tourism and Service, Moscow, Russian Federation
}

\begin{abstract}
Searching for the most energy efficient solutions in the field of household refrigerating appliances is an urgent issue. Development of modern energy efficient models of household refrigerators and freezers should be based on new flowcharts and new theoretical and experimental studies, which would determine the importance of proposed concepts.

This work compares the main parameters of thermodynamic efficiency of the developed refrigerating unit in comparison with existing appliances using ozone-safe R134a and R600a refrigerants.

This work presents the pressure-enthalpy diagram of the developed household refrigerator; using this diagram, the main properties of thermodynamic efficiency of refrigerating unit have been determined.
\end{abstract}

The performed studies based on the theory of thermodynamics and heat exchange demonstrate increase in such parameters of thermodynamic efficiency as specific refrigerating capacity and cooling factor of theoretical cycle of modernized refrigerating unit of household refrigerator.

On the basis of the obtained data, it is possible to conclude that application of additional heat exchangers and vapor separators allows to increase energy efficiency of refrigerating unit as well as to improve its refrigerating capacity; and parallel supply of refrigerant to evaporators of low temperature and freezing compartment results in boiling of only a portion of liquid refrigerant in freezing compartment evaporator. In its turn, this promotes decrease in time required for defrosting of freezing compartment evaporator, thus increasing energy efficiency of refrigerator due to elimination of electric heater for defrosting of freezing compartment evaporator from total electric circuit.

Key words: refrigerating unit, energy efficiency, thermodynamic efficiency, refrigerating capacity, cooling factor, theoretical cycle.

\section{INTRODUCTION}

The modern trends of development of household compression refrigerators are aimed at improvement of their energy efficiency and reliability. One of the main trends of solution to this problem is increase in thermodynamic efficiency of the cycles based on analysis of processes in refrigerating unit [1, $2,3]$.

At present, household refrigerators mainly operate with two ozone-safe refrigerants: R134a (CF3CFH2 - tetra fluoroethane) and R600a (C4H10 - isobutane). In terms of environmental safety, R600a as refrigerant is characterized by obvious advantages with regard to the impact on the Earth ozone layer: $\mathrm{ODP}=0$, and possible occurrence of greenhouse effect: GWP $=0.001[1,4,5,6]$.

Power consumptions of compression household refrigerators are $60-70 \%$ of total household power consumptions. Two-compartment household refrigerators constitute more than one half of all proposals in the market of refrigerating appliances [7, 8, 9].

Heat exchangers in household compression refrigerators allow to increase thermo dynamical efficiency of cooling cycle [10-16].

The main aim of this work is determination of efficiency of additional heat exchangers and vapor separator in a modernized refrigerating unit, as well as consideration of possible increase in energy efficiency and refrigerating capacity of household two-compartment refrigerators by means of improvement of refrigerating unit.

\section{METHODS}

The work was performed using theoretical methods. Theoretical studies were based on the theory of thermodynamics and heat exchange.

\section{RESULTS AND DISCUSSION}

This work theoretically analyzes the thermodynamic efficiency of cycles with R134a and R600a refrigerants.

Conventional flowchart of refrigerating unit with two consecutively connected evaporators used in two-compartment refrigerators was used as the basic model. The developed flowchart of refrigerating unit [10, 17] illustrated in Figure 1 was used for comparison. 


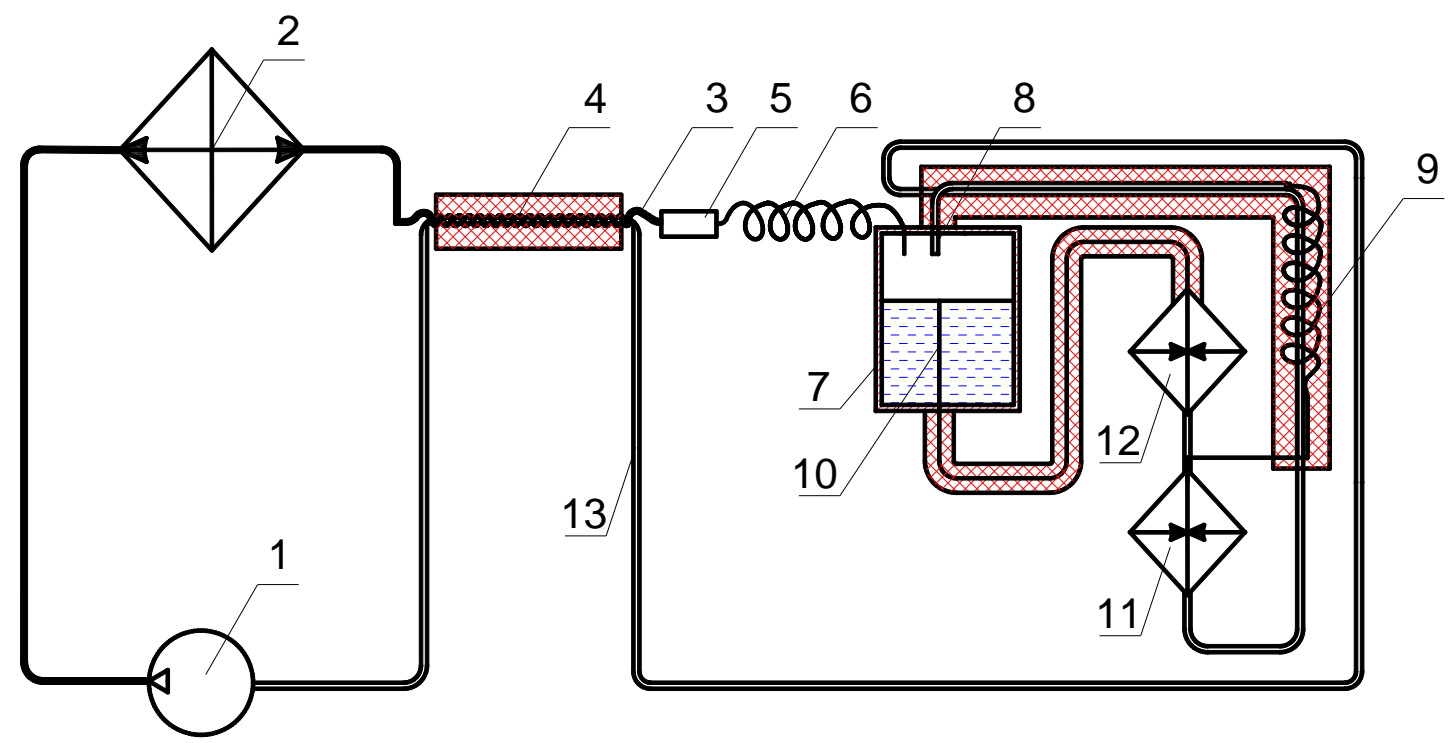

Figure 1: Refrigerating unit flowchart $[10,17]$

The refrigerating unit (Figure 1) is comprised of the compressor 1 connected by injection pipeline with the condenser 2. After the condenser the pipeline 3 is installed, which, in combination with a part of the suction pipeline 13, forms the first heat exchanger 4 . The outlet of the pipeline 3 via the drying filter 5 is connected with the first capillary tube 6 . The capillary tube 6 is connected with the inlet of the vapor separator 7. The second capillary tube 8 comes out of the top part of the vapor separator 7 , which, in combination with a part of the suction pipeline 13, forms the second heat exchanger 9. The outlet of the second capillary tube 8 is connected with the freezing compartment evaporator 11 . The second outlet from the bottom part of the vapor separator 7 is connected via the second capillary tube 10 with the inlet of the low-temperature compartment evaporator 12 , its outlet is consecutively connected with the freezing compartment evaporator 11.

Thermodynamic analysis of the cycles of refrigerating units operating with R134a and R600a refrigerants should be reasonable to perform using pressure-enthalpy diagram (Figure 2). The curves of theoretical cycle of the developed refrigerating unit are highlighted in blue. Using this diagram, it is possible to determine the main properties of thermodynamic efficiency [8]:

-specific refrigerating capacity $\mathrm{q}_{0}, \mathrm{~kJ} / \mathrm{kg}$;

-specific isentropic performance of compressor ls, $\mathrm{kJ} / \mathrm{kg}$;

-specific heat rejected in condenser $\mathrm{q}_{\mathrm{con}}, \mathrm{kJ} / \mathrm{kg}$;

-cooling factor of the theoretical cycle.

\section{Cycle of the developed refrigerating unit}

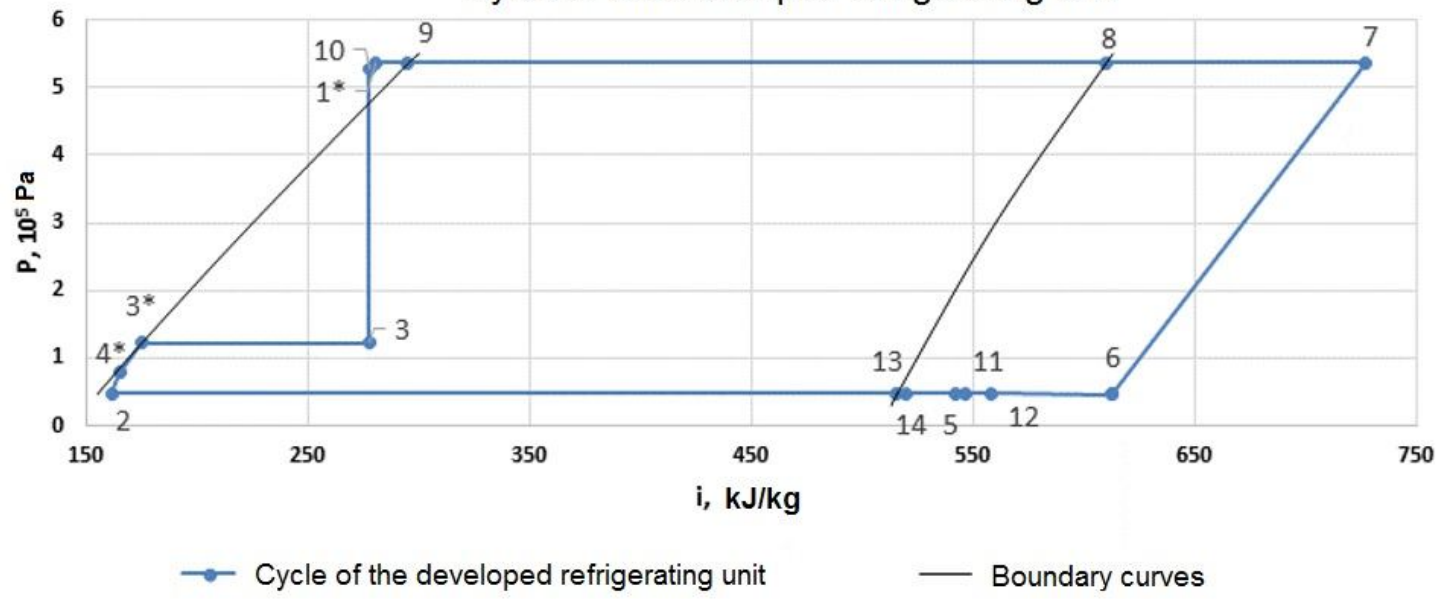

Figure 2: Theoretical cycle of the developed refrigerating unit in P-I diagram. $\mathrm{T}_{0}=-30^{\circ} \mathrm{C}, \mathrm{T}_{\mathrm{amb}}=32^{\circ} \mathrm{C}, \mathrm{T}_{\text {con }}=40^{\circ} \mathrm{C}$ 
The following initial data were used for the calculations:

$$
\begin{array}{lll}
\mathrm{t}_{\mathrm{o}}=-0^{\circ} \mathrm{C} ; & \mathrm{t}_{\mathrm{o}}=-20^{\circ} \mathrm{C} ; & \mathrm{t}_{\mathrm{o}}=-30^{\circ} \mathrm{C} ; \\
\mathrm{t}_{\mathrm{con}}=23^{\circ} \mathrm{C} ; & \mathrm{t}_{\mathrm{con}}=23^{\circ} \mathrm{C} ; & \mathrm{t}_{\mathrm{con}}=23^{\circ} \mathrm{C} ; \\
\mathrm{t}_{\mathrm{amb}}=16^{\circ} \mathrm{C} ; & \mathrm{t}_{\mathrm{amb}}=16^{\circ} \mathrm{C} ; & \mathrm{t}_{\mathrm{amb}}=16^{\circ} \mathrm{C} ; \\
\mathrm{t}_{\mathrm{oh}}=16^{\circ} \mathrm{C} ; & \mathrm{t}_{\mathrm{oh}}=16^{\circ} \mathrm{C} ; & \mathrm{t}_{\mathrm{oh}}=16^{\circ} \mathrm{C} ; \\
\mathrm{t}_{\mathrm{oc}}=19^{\circ} \mathrm{C}, & \mathrm{t}_{\mathrm{oc}}=19^{\circ} \mathrm{C}, & \mathrm{t}_{\mathrm{oc}}=19^{\circ} \mathrm{C} \\
\mathrm{t}_{\mathrm{o}}=-10^{\circ} \mathrm{C} ; & \mathrm{t}_{\mathrm{o}}=-20^{\circ} \mathrm{C} ; & \mathrm{t}_{\mathrm{o}}=-30^{\circ} \mathrm{C} ; \\
\mathrm{t}_{\mathrm{con}}=40^{\circ} \mathrm{C} ; & \mathrm{t}_{\mathrm{con}}=40^{\circ} \mathrm{C} ; & \mathrm{t}_{\mathrm{con}}=40^{\circ} \mathrm{C} ; \\
\mathrm{t}_{\mathrm{amb}}=32^{\circ} \mathrm{C} ; & \mathrm{t}_{\mathrm{amb}}=32^{\circ} \mathrm{C} ; & \mathrm{t}_{\mathrm{amb}}=32^{\circ} \mathrm{C} ; \\
\mathrm{t}_{\mathrm{oh}}=32^{\circ} \mathrm{C} ; & \mathrm{t}_{\mathrm{oh}}=32^{\circ} \mathrm{C} ; & \mathrm{t}_{\mathrm{oh}}=32^{\circ} \mathrm{C} ; \\
\mathrm{t}_{\mathrm{cc}}=36^{\circ} \mathrm{C}, & \mathrm{t}_{\mathrm{oc}}=36^{\circ} \mathrm{C}, & \mathrm{t}_{\mathrm{oc}}=36^{\circ} \mathrm{C}, \\
\mathrm{t}_{\mathrm{o}}=-10^{\circ} \mathrm{C} ; & \mathrm{t}_{\mathrm{o}}=-20^{\circ} \mathrm{C} ; & \mathrm{t}_{\mathrm{o}}=-30^{\circ} \mathrm{C} ; \\
\mathrm{t}_{\mathrm{con}}=33^{\circ} \mathrm{C} ; & \mathrm{t}_{\mathrm{con}}=33^{\circ} \mathrm{C} ; & \mathrm{t}_{\mathrm{con}}=33^{\circ} \mathrm{C} ; \\
\mathrm{t}_{\mathrm{amb}}=25^{\circ} \mathrm{C} ; & \mathrm{t}_{\mathrm{amb}}=25^{\circ} \mathrm{C} ; & \mathrm{t}_{\mathrm{amb}}=25^{\circ} \mathrm{C} ; \\
\mathrm{t}_{\mathrm{oh}}=25^{\circ} \mathrm{C} ; & \mathrm{t}_{\mathrm{oh}}=25^{\circ} \mathrm{C} ; & \mathrm{t}_{\mathrm{oh}}=25^{\circ} \mathrm{C} ; \\
\mathrm{t}_{\mathrm{oc}}=29^{\circ} \mathrm{C}, & \mathrm{t}_{\mathrm{oc}}=29^{\circ} \mathrm{C}, & \mathrm{t}_{\mathrm{oc}}=29^{\circ} \mathrm{C},
\end{array}
$$

where $t_{0}$ was the temperature of refrigerant boiling, $t_{\text {con }}$ was the temperature of condensation, $t_{a m b}$ was the ambient temperature, $t_{\mathrm{oh}}$ was the overheating temperature of suction vapors, $t_{o c}$ was the overcooling temperature of liquid refrigerant after condensation.

The main properties of thermodynamic efficiency of cycle are calculated by Eqs. (1)-(4) [10].

1. Specific refrigerating capacity, $\mathrm{kJ} / \mathrm{kg}$ :

$$
\mathrm{q}_{\mathrm{o}}=\mathrm{i}_{5}-\mathrm{i}_{2}
$$

2. Specific isentropic performance of compressor, $\mathrm{kJ} / \mathrm{kg}$ :

$$
\mathrm{l}_{\mathrm{s}}=\mathrm{i}_{7}-\mathrm{i}_{6}
$$

3. Specific heat rejected in condenser, $\mathrm{kJ} / \mathrm{kg}$ :

$$
\mathrm{q}_{\mathrm{con}}=\mathrm{i}_{8}-\mathrm{i}_{9}
$$

4. Cooling factor of theoretical cycle:

$$
\varepsilon=\mathrm{q}_{\mathrm{o}} / \mathrm{l}_{\mathrm{s}}
$$

On the basis of the performed calculations, it is possible to plot comparative diagrams of thermodynamic efficiency of such properties as specific refrigerating capacity and cooling factor of the theoretical cycle (Figures 3 and 4) for R134a and R600a refrigerants.

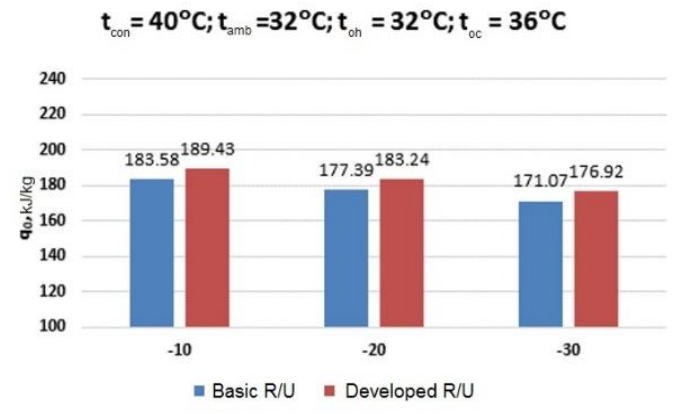

a)

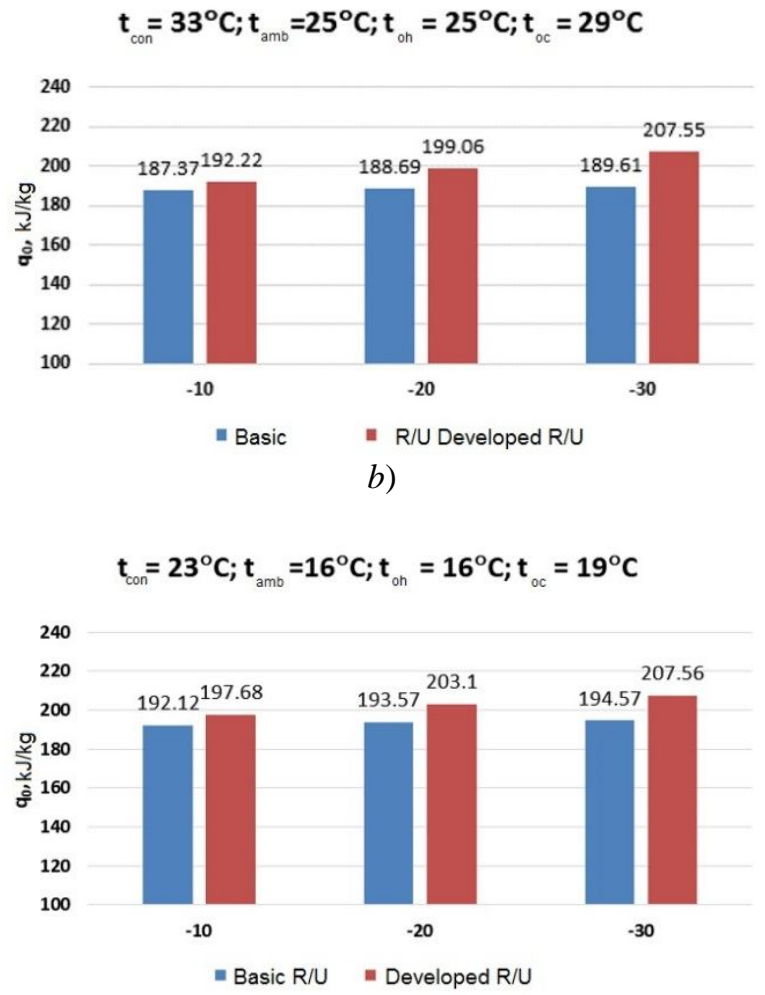

c)

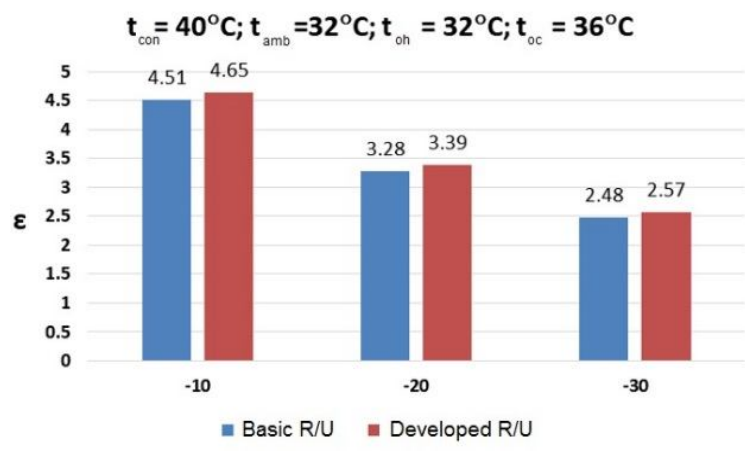

d)

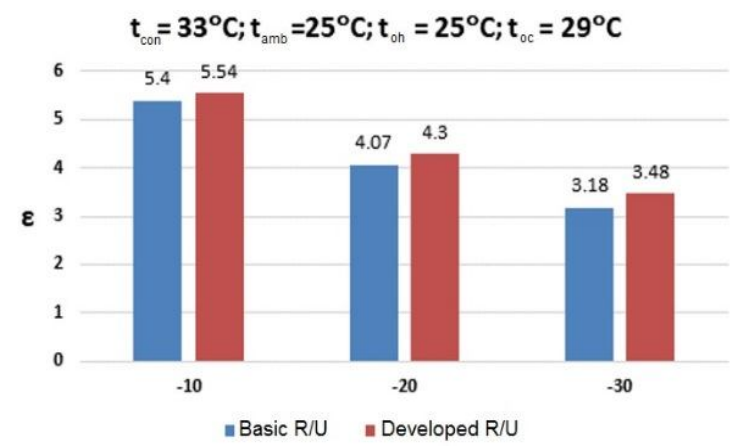

e) 


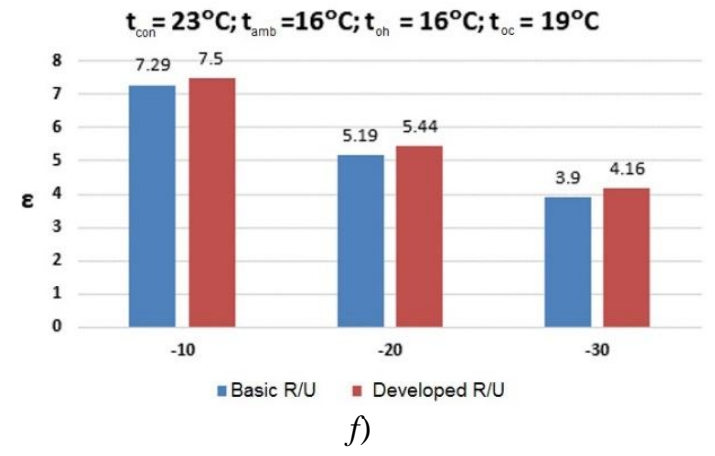

Figure 3: Comparison of main properties of thermodynamic efficiency of cycle of the basic and the developed refrigerating unit with R134a refrigerant operating in various modes:

a) specific refrigerating capacity at: $\mathrm{t}_{\mathrm{con}}=40^{\circ} \mathrm{C} ; \mathrm{t}_{\mathrm{amb}}=32^{\circ} \mathrm{C}$; $\mathrm{t}_{\mathrm{oh}}=32^{\circ} \mathrm{C} ; \mathrm{t}_{\mathrm{oc}}=36^{\circ} \mathrm{C}$;

b) specific refrigerating capacity at: $\mathrm{t}_{\mathrm{con}}=33^{\circ} \mathrm{C} ; \mathrm{t}_{\mathrm{amb}}=25^{\circ} \mathrm{C}$; $\mathrm{t}_{\mathrm{oh}}=25^{\circ} \mathrm{C} ; \mathrm{t}_{\mathrm{oc}}=29^{\circ} \mathrm{C}$;

c) specific refrigerating capacity at: $\mathrm{t}_{\mathrm{con}}=23^{\circ} \mathrm{C} ; \mathrm{t}_{\mathrm{amb}}=16^{\circ} \mathrm{C}$; $\mathrm{t}_{\mathrm{oh}}=16^{\circ} \mathrm{C} ; \mathrm{t}_{\mathrm{oc}}=19^{\circ} \mathrm{C}$;

d) cooling factor of theoretical cycle at: $\mathrm{t}_{\mathrm{con}}=40^{\circ} \mathrm{C} ; \mathrm{t}_{\mathrm{amb}}$ $=32^{\circ} \mathrm{C} ; \mathrm{t}_{\mathrm{oh}}=32^{\circ} \mathrm{C} ; \mathrm{t}_{\mathrm{oc}}=36^{\circ} \mathrm{C}$;

e) cooling factor of theoretical cycle at: $\mathrm{t}_{\mathrm{con}}=33^{\circ} \mathrm{C} ; \mathrm{t}_{\mathrm{amb}}$ $=25^{\circ} \mathrm{C} ; \mathrm{t}_{\mathrm{oh}}=25^{\circ} \mathrm{C} ; \mathrm{t}_{\mathrm{oc}}=29^{\circ} \mathrm{C}$;

f) cooling factor of theoretical cycle at: $\mathrm{t}_{\mathrm{con}}=23^{\circ} \mathrm{C} ; \mathrm{t}_{\mathrm{amb}}$ $=16^{\circ} \mathrm{C} ; \mathrm{t}_{\mathrm{oh}}=16^{\circ} \mathrm{C} ; \mathrm{t}_{\mathrm{oc}}=19^{\circ} \mathrm{C}$

It can be seen in Figure 3 that the specific refrigerating capacity for R134a refrigerant at initial $\mathrm{t}_{\mathrm{con}}=40^{\circ} \mathrm{C} ; \mathrm{t}_{\mathrm{amb}}$ $=32^{\circ} \mathrm{C} ; \mathrm{t}_{\mathrm{oh}}=32^{\circ} \mathrm{C} ; \mathrm{t}_{\mathrm{oc}}=36^{\circ} \mathrm{C}$ (Figure $3 \mathrm{a}$ ) tends to decrease with decrease in refrigerant boiling point from -10 to $-30^{\circ} \mathrm{C}$ :

at $\mathrm{t}_{0}=-10^{\circ} \mathrm{C}$

$183.58 \mathrm{~kJ} / \mathrm{kg}$ - for basic refrigerating unit;

$189.43 \mathrm{~kJ} / \mathrm{kg}$ - for the developed refrigerating unit.

at $\mathrm{t}_{0}=-20^{\circ} \mathrm{C}$

$177.39 \mathrm{~kJ} / \mathrm{kg}$ - for basic refrigerating unit;

$183.24 \mathrm{~kJ} / \mathrm{kg}$ - for the developed refrigerating unit.

at $\mathrm{t}_{0}=-30^{\circ} \mathrm{C}$

$171.07 \mathrm{~kJ} / \mathrm{kg}$ - for basic refrigerating unit;

$176.92 \mathrm{~kJ} / \mathrm{kg}$ - for the developed refrigerating unit.

Cooling factor of the theoretical cycle (Figure $3 d, e, f$ ) in this case decreases with decrease in boiling point at all initial temperatures.

Increase in specific refrigerating capacity and cooling factor of the theoretical cycle in the developed refrigerating unit with regard to basic one at initial $\mathrm{t}_{\mathrm{con}}=40^{\circ} \mathrm{C} ; \mathrm{t}_{\mathrm{amb}}=32^{\circ} \mathrm{C} ; \mathrm{t}_{\mathrm{oh}}=$ $32^{\circ} \mathrm{C} ; \mathrm{t}_{\mathrm{oc}}=36^{\circ} \mathrm{C}$ (Figure $3 a, d$ ) was about $3 \%$ and actually does not depend on the refrigerant boiling point.
At initial $\mathrm{t}_{\mathrm{con}}=33^{\circ} \mathrm{C} ; \mathrm{t}_{\mathrm{amb}}=25^{\circ} \mathrm{C} ; \mathrm{t}_{\mathrm{oh}}=25^{\circ} \mathrm{C} ; \mathrm{t}_{\mathrm{oc}}=29^{\circ} \mathrm{C}$ and $\mathrm{t}_{\text {con }}=23^{\circ} \mathrm{C} ; \mathrm{t}_{\mathrm{amb}}=16^{\circ} \mathrm{C} ; \mathrm{t}_{\mathrm{oh}}=16^{\circ} \mathrm{C} ; \mathrm{t}_{\mathrm{oc}}=19^{\circ} \mathrm{C}$ (Figure $3 \mathrm{~b}, \mathrm{c}$ ), it is possible to observe increase in specific refrigerating capacity with decrease in refrigerant boiling point. Similarly, at the same parameters increase in specific refrigerating capacity and cooling factor of the theoretical cycle is observed upon comparison of the developed and basic refrigerating unit as a function of refrigerant boiling point:

at $\mathrm{t}_{0}=-10^{\circ} \mathrm{C}$

$2.5 \%$ for $\mathrm{t}_{\mathrm{con}}=33^{\circ} \mathrm{C} ; \mathrm{t}_{\mathrm{amb}}=25^{\circ} \mathrm{C} ; \mathrm{t}_{\mathrm{oh}}=25^{\circ} \mathrm{C} ; \mathrm{t}_{\mathrm{oc}}=29^{\circ} \mathrm{C}$;

$2.8 \%$ for $\mathrm{t}_{\mathrm{con}}=23^{\circ} \mathrm{C} ; \mathrm{t}_{\mathrm{amb}}=16^{\circ} \mathrm{C} ; \mathrm{t}_{\mathrm{oh}}=16^{\circ} \mathrm{C} ; \mathrm{t}_{\mathrm{oc}}=19^{\circ} \mathrm{C}$;

at $\mathrm{t}_{0}=-20^{\circ} \mathrm{C}$

$5.2 \%$ for $\mathrm{t}_{\mathrm{con}}=33^{\circ} \mathrm{C} ; \mathrm{t}_{\mathrm{amb}}=25^{\circ} \mathrm{C} ; \mathrm{t}_{\mathrm{oh}}=25^{\circ} \mathrm{C} ; \mathrm{t}_{\mathrm{oc}}=29^{\circ} \mathrm{C}$;

$4.7 \%$ for $\mathrm{t}_{\mathrm{con}}=23^{\circ} \mathrm{C} ; \mathrm{t}_{\mathrm{amb}}=16^{\circ} \mathrm{C} ; \mathrm{t}_{\mathrm{oh}}=16^{\circ} \mathrm{C} ; \mathrm{t}_{\mathrm{oc}}=19^{\circ} \mathrm{C}$;

at $\mathrm{t}_{0}=-30^{\circ} \mathrm{C}$

$8.6 \%$ for $\mathrm{t}_{\mathrm{con}}=33^{\circ} \mathrm{C} ; \mathrm{t}_{\mathrm{amb}}=25^{\circ} \mathrm{C} ; \mathrm{t}_{\mathrm{oh}}=25^{\circ} \mathrm{C} ; \mathrm{t}_{\mathrm{oc}}=29^{\circ} \mathrm{C}$;

$6.3 \%$ for $\mathrm{t}_{\mathrm{con}}=23^{\circ} \mathrm{C} ; \mathrm{t}_{\mathrm{amb}}=16^{\circ} \mathrm{C} ; \mathrm{t}_{\mathrm{oh}}=16^{\circ} \mathrm{C} ; \mathrm{t}_{\mathrm{oc}}=19^{\circ} \mathrm{C}$;

Comparison of the main properties of thermodynamic efficiency of the cycle of the basic and developed refrigerating unit operating with R600a refrigerant in various modes is illustrated in Figure 4.

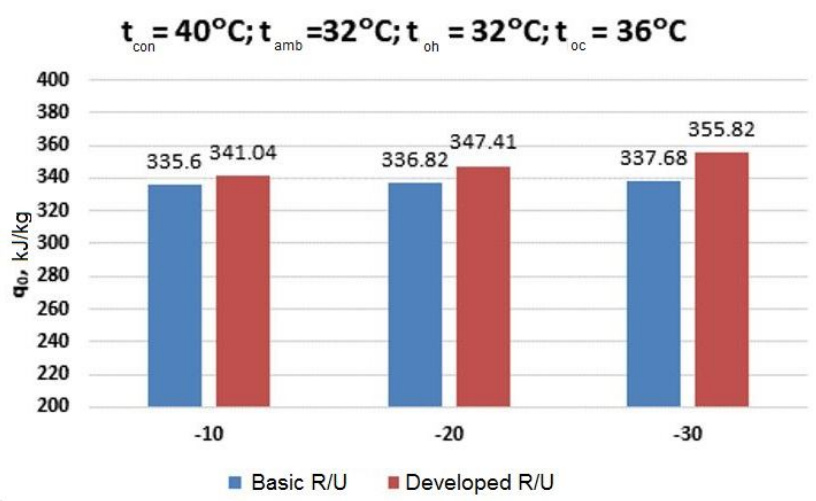

a)

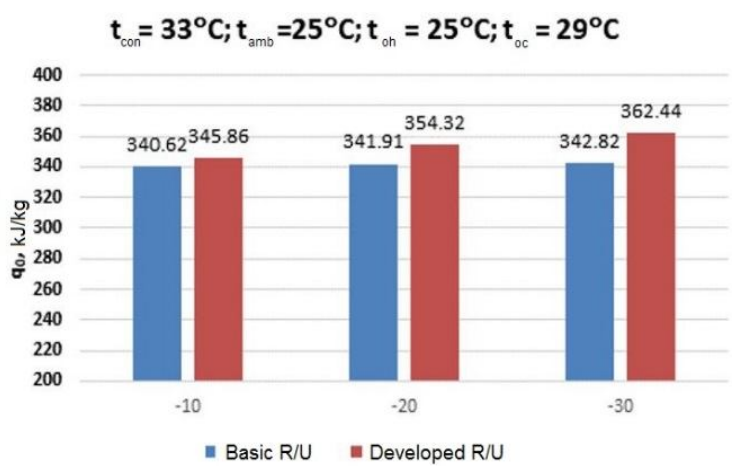

b) 


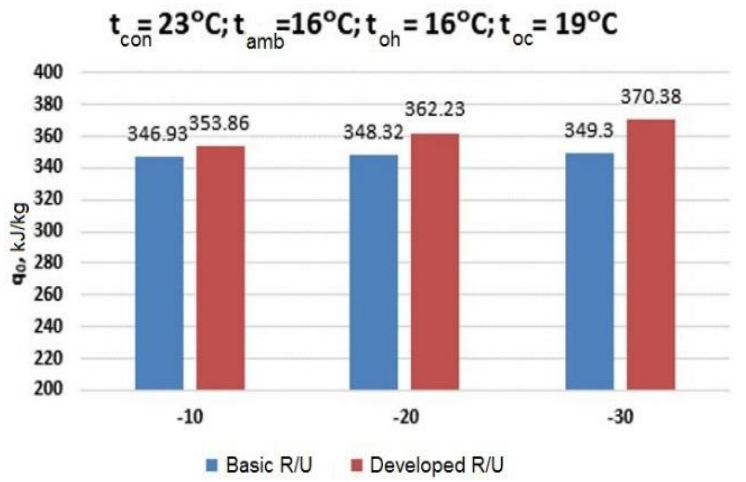

c)

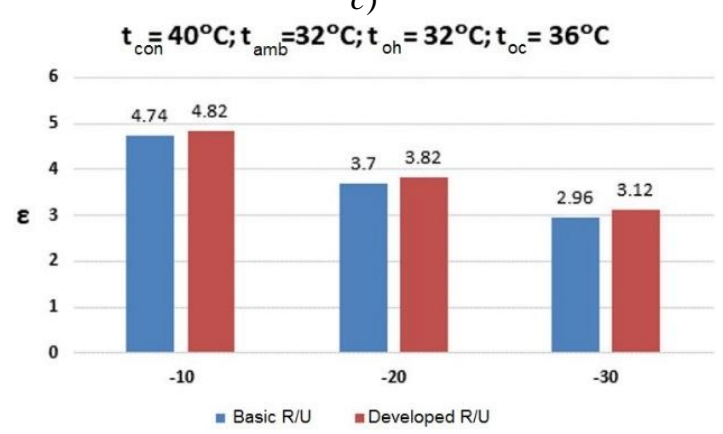

d)

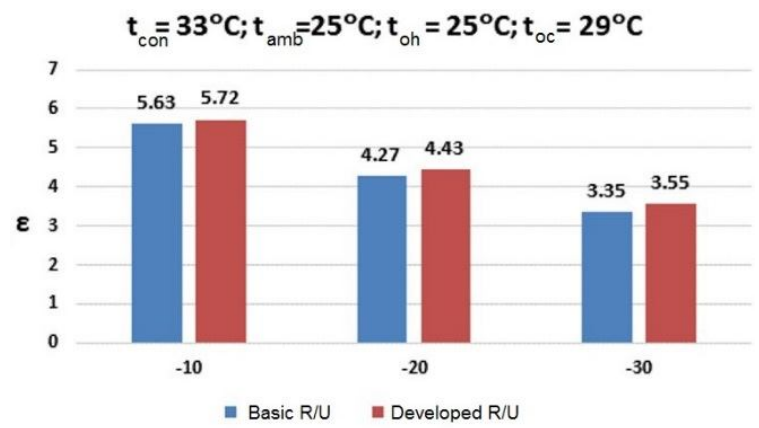

e)

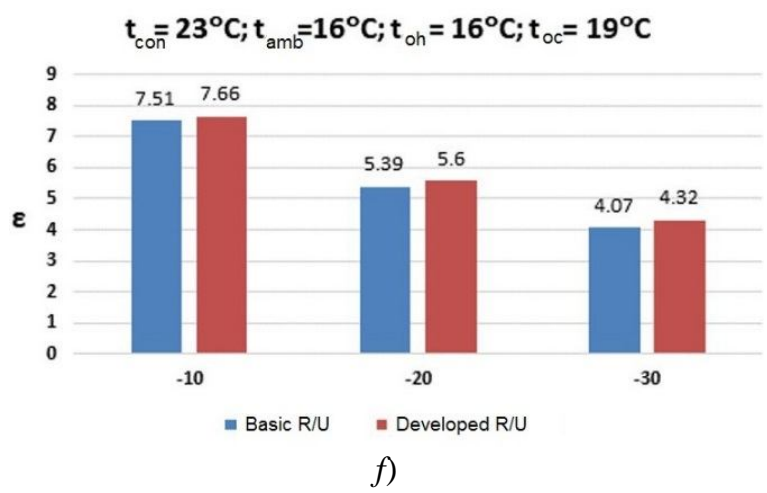

Figure 4: Comparison of main properties of thermodynamic efficiency of cycle of the basic and the developed refrigerating unit with R600a refrigerant operating in various modes:

a) specific refrigerating capacity at: $\mathrm{t}_{\mathrm{con}}=40^{\circ} \mathrm{C} ; \mathrm{t}_{\mathrm{amb}}=32^{\circ} \mathrm{C}$; $\mathrm{t}_{\mathrm{oh}}=32^{\circ} \mathrm{C} ; \mathrm{t}_{\mathrm{oc}}=36^{\circ} \mathrm{C}$;

b) specific refrigerating capacity at: $\mathrm{t}_{\mathrm{con}}=33^{\circ} \mathrm{C} ; \mathrm{t}_{\mathrm{amb}}=25^{\circ} \mathrm{C}$; $\mathrm{t}_{\mathrm{oh}}=25^{\circ} \mathrm{C} ; \mathrm{t}_{\mathrm{oc}}=29^{\circ} \mathrm{C}$; c) specific refrigerating capacity at: $\mathrm{t}_{\mathrm{con}}=23^{\circ} \mathrm{C} ; \mathrm{t}_{\mathrm{amb}}=16^{\circ} \mathrm{C}$; $\mathrm{t}_{\mathrm{oh}}=16^{\circ} \mathrm{C} ; \mathrm{t}_{\mathrm{oc}}=19^{\circ} \mathrm{C}$

d) cooling factor of theoretical cycle at: $\mathrm{t}_{\mathrm{con}}=40^{\circ} \mathrm{C} ; \mathrm{t}_{\mathrm{amb}}$ $=32^{\circ} \mathrm{C} ; \mathrm{t}_{\mathrm{oh}}=32^{\circ} \mathrm{C} ; \mathrm{t}_{\mathrm{oc}}=36^{\circ} \mathrm{C}$;

e) cooling factor of theoretical cycle at: $\mathrm{t}_{\mathrm{con}}=33^{\circ} \mathrm{C} ; \mathrm{t}_{\mathrm{amb}}$ $=25^{\circ} \mathrm{C} ; \mathrm{t}_{\mathrm{oh}}=25^{\circ} \mathrm{C} ; \mathrm{t}_{\mathrm{oc}}=29^{\circ} \mathrm{C}$;

f) cooling factor of theoretical cycle at: $\mathrm{t}_{\mathrm{con}}=23^{\circ} \mathrm{C} ; \mathrm{t}_{\mathrm{amb}}$ $=16^{\circ} \mathrm{C} ; \mathrm{t}_{\mathrm{oh}}=16^{\circ} \mathrm{C} ; \mathrm{t}_{\mathrm{oc}}=19^{\circ} \mathrm{C}$

While analyzing the main properties of thermodynamic efficiency of the basic and the developed refrigerating unit operating with R600a refrigerant (Figure 4), it can be seen that the specific refrigerating capacity at all initial temperatures (Figure $4 a, b, c$ ) increases with decrease in boiling point of the refrigerant $\mathrm{t}_{0}$ from -10 to $-30^{\circ} \mathrm{C}$.

Cooling factor of the theoretical cycle (Figure $4 d, e, f$ ) decreases with decrease in the boiling point at all initial temperatures as in the case with R134a refrigerant.

The increase in specific refrigerating capacity and cooling factor of the theoretical cycle in the developed refrigerating unit with regard to the basic one is as follows:

from 1.5 to $2 \%$ at $\mathrm{t}_{0}=-10^{\circ} \mathrm{C}$;

from 3 to $3.8 \%$ at $\mathrm{t}_{0}=-20^{\circ} \mathrm{C}$;

from 5 to $5.7 \%$ at $\mathrm{t}_{0}=-30^{\circ} \mathrm{C}$.

\section{CONCLUSION}

1. Increase in properties of both refrigerants was observed in the work:

- R134a refrigerant demonstrated increase in the specific refrigerating capacity and cooling factor of theoretical cycle from 2.5 to $8.6 \%$. Maximum values were achieved at: $t_{0}=-$ $30^{\circ} \mathrm{C} ; \mathrm{t}_{\mathrm{con}}=33^{\circ} \mathrm{C} ; \mathrm{t}_{\mathrm{amb}}=25^{\circ} \mathrm{C} ; \mathrm{t}_{\mathrm{oh}}=25^{\circ} \mathrm{C} ; \mathrm{t}_{\mathrm{oc}}=29^{\circ} \mathrm{C}$;

- $\quad$ the properties of R600a refrigerant increased from 1.5 to $5.7 \%$. Maximum values were achieved at: $\mathrm{t}_{\mathrm{o}}=-30^{\circ} \mathrm{C} ; \mathrm{t}_{\mathrm{con}}=$ $23^{\circ} \mathrm{C} ; \mathrm{t}_{\mathrm{amb}}=16^{\circ} \mathrm{C} ; \mathrm{t}_{\mathrm{oh}}=16^{\circ} \mathrm{C} ; \mathrm{t}_{\mathrm{oc}}=19^{\circ} \mathrm{C}$.

2. Therefore, the proposed engineering solution allowed to increase energy efficiency of refrigerating unit, as well as to increase its refrigerating capacity.

\section{REFERENCES}

1. Yu.V. Kudrov, Ya.A. Sirotenko, L.V Sumzina. Eksperimental'nye ustanovki dlya issledovaniya protsessa drosselirovaniya v kapillyarnykh trubkakh bytovykh kholodil'nikov [Experimental facilities for analysis of throttling in capillary tubes of household refrigerators], in: Modern problems of tourism and service. Proceedings: All-Russian Conference of Postgraduates and Young Scientists, 2013, pp. 198-202.

2. L.V. Sumzina, A.V. Maksimov. Analiz poter' eksergii v tsikle kompressionnogo bytovogo kholodil'nika 
[Analysis of exergy loss in a cycle of household compressor refrigerator], Elektrotekhnicheskie $i$ informatsionnye kompleksy i sistemy, Vol. 8, No. 1, pp. 37-39, 2012.

3. A.A. Vasserman, G.K. Lavrenchenko, A.G. Slyn'ko. Osobennosti idealizirovannykh tsiklov parokompressornykh kholodil'nykh mashin [Peculiar features of idealized cycles of vapor compression refrigerating machines], Tekhnicheskie gazy, Vol. 6, pp. 30-36, 2014.

4. L.V. Sumzina, A.V. Maksimov, Yu.V. Kudrov. Sravnitel'nyi analiz tsiklov bytovogo kholodil'nika na khladagentakh R134A, R600A [Comparative analysis of cycles of household refrigerators with R314a and R600a refrigerants], Elektrotekhnicheskie $i$ informatsionnye kompleksy i sistemy, Vol. 8, No. 2, pp. 57-59, 2012.

5. A.V. Maksimov, Yu.V. Kudrov, F.A. Ravilov, L.A. Burtseva. Osobennosti protsessa drosselirovaniya khladagenta $\mathbf{v}$ kapillyarnykh trubkakh [Peculiar features of refrigerant throttling in capillary tubes], Russian journal of resources, conservation and recycling, Vol. 3, No. 2, pp. 1-8, 2016. Available at http://resources.today/PDF/01RRO216.pdf

6. A. Demenev, A. Naberezhnykh. Research of the process of formation of noise in Household Refrigerators, Akustika, Vol. 32, pp. 135-137, 2019. https://doi.org/10.36336/akustika201932135

7. L.V. Sumzina, Ya.A. Kochetkova, P.A. Arzhanov, I.A. Burtsev, A.A. Litvinenko. Vliyanie rekuperativnogo teploobmena na effektivnost' tsikla kholodil'nogo agregata [The influence of recuperating heat exchange on the cycle efficiency of refrigerating unit], Russian journal of resources, conservation and recycling, Vol. 3, No. 2, pp. 1-9, 2016. Available at http://resources.today/PDF/07RRO216.pdf

8. M.A. Lemeshko. Tekhnologii povysheniya energeticheskoi effektivnosti bytovykh kholodil'nykh priborov [Improvement of energy efficiency of household refrigerators], Fundamental'nye i prikladnye issledovaniya: problemy $i$ rezul'taty, Vol. 13, pp. 188-196, 2014.

9. V.S. Reznikov, P.V. Romanov. Analiz metodov uvelicheniya energoeffektivnosti kompressionnykh kholodil'nikov [Analysis of improvement of energy efficiency of compressor refrigerators], Intellektual'nyi potentsial XXI veka: stupeni poznaniya, Vol. 23, pp. 143-146, 2014.

10. L.V. Sumzina, A.V. Maksimov, Yu.V. Kudrov, A.S. Kochetkov. Energoeffektivnyi kholodil'nyi agregat dlya dvukhkamernykh kholodil'nikov i morozil'nikov bytovogo i promyshlennogo naznacheniya [Energy efficient refrigerating unit of household and commercial two-compartment refrigerators and freezers], Promyshlennyi servis, Vol. 1, No. 70, pp. 24-26, 2019.

11. I.M. Kalnin', K.N. Fadekov. Otsenka effektivnosti termodinamicheskikh tsiklov parokompressionnykh kholodil'nykh mashin i teplovykh nasosov [Efficiency estimation of thermodynamic cycles of vapor compression refrigerators and heat pumps], Kholodil'naya tekhnika, Vol. 3, pp. 16-25, 2006.

12. Improvement of refrigerator energy efficiency: RF Patent 2630813; published May 04, 2017, Byul. No. 13.

13. Cooling unit of household freezers: RF Patent 1155868; published October 20, 2015, Byul. No. 29.

14. Cooling unit with heat exchanger-receiver: RF Patent 1555867; published October 20, 2015, Byul. No. 29.

15. A.V. Maksimov, V.V. Kolyada, Ya.A. Sirotenko. Zavisimost' pokazatelei termodinamicheskoi effektivnosti tsikla kholodil'nogo agregata ot temperatury pereokhlazhdeniya $\mathrm{v}$ teploobmennike [Thermodynamic efficiency of refrigerator cycle as a function of overcooling temperature in heat exchanger], Elektrotekhnicheskie $i$ informatsionnye kompleksy $i$ sistemy, Vol. 8, No. 2, pp. 60-64, 2012.

16. L.V. Sumzina. Improvement of energy efficiency of household compressor refrigerators with double evaporative cooling system, Cand. thesis: 05.02.13, Moscow Technological Institute, Moscow, Russia, 1990.

17. Cooling unit for two-compartment refrigerator: RF Patent 186269; published January 15, 2019, Byul. No. 2. 